\title{
Meteorological Parameters: Effect of Different Environments on Seed Germination in Upland Cotton (Gossypium hirsutum L.)
}

\author{
Pinki*, S.S. Siwach and Neha Rohila \\ Haryana Agricultural University, Hisar, Haryana, India \\ *Corresponding author
}

\section{A B S T R A C T}

\begin{tabular}{|c|}
\hline Keywords \\
\hline $\begin{array}{l}\text { meteorological } \\
\text { parameters, Seed } \\
\text { germination, } \\
\text { Different } \\
\text { environments }\end{array}$ \\
\hline Article Info \\
\hline $\begin{array}{l}\text { Accepted: } \\
10 \text { November } 2018 \\
\text { Available Online: } \\
10 \text { December } 2018\end{array}$ \\
\hline
\end{tabular}

\section{Introduction}

Environmental factors for optimum seed germination plays a vital role in realizing crop growth and yields. The time of sowings as varied growth condition for various crops differs depending on climate and varieties. Knowledge on effects of various elements of environment on crop growth, development and yield is important to harness good crop yield with better quality of seed and fiber. Seed quality aspects mainly seed vigor and viability plays an important role in seed germination. Seed germination in cotton is a big problem under North Indian conditions. It remains much below the standard germination because of poor seed development and its quality is very much affected by environment. Sometimes seed germination in cotton may be reduced as low as $10 \%$ due to adverse environmental conditions and exact reasons for poor development of seed are not known. To overcome this problem present investigation was planned.

\section{Materials and Method}

experiment was conducted during kharif 2015 and 2016 having three cultivars H 1098-I, H 1300 and $\mathrm{H} 1316$ of upland cotton grown at CCS Haryana Agricultural University, Hisar in randomized block design replicated six 
times each in eight rows of $6 \mathrm{~m}$ length with a spacing of $67.5 \times 30 \mathrm{~cm}$. These varieties were grown in six environments that comprises of three sowings periods (Early: first fortnight of April, normal: first fortnight of May and late: end of May/early June) during the year 2015 and 2016 (Table 1).

Data was recorded as in all the three replications in every week flowers were tagged and number of effective bolls formed from these flowers was counted and the week in which maximum and minimum bolls developed was identified. The seed cotton from these opened bolls was picked separately and ginned. This seed was used to test the seed quality parameters. These seed quality traits were correlated with different weather parameters to pin point the reasons for good or poor seed developments. The data on meteorological aspects was recorded from tagging period i.e. June, 24 to till the last picking of the experimental plots.

Meteorological data was recorded as:

Maximum and minimum temperature $\left({ }^{\circ} \mathrm{C}\right)$

Maximum and minimum temperature was calculated as the average temperature of different weeks and then averaged.

Relative humidity (\%) morning as well as evening

Relative humidity morning as well as evening was calculated as the average relative humidity of morning and evening of different tagging weeks and the averaged.

Sunshine hours

Sunshine hours were calculated as the average sunshine hours of different tagging weeks and the averaged.
Rainfall (mm) \& number of rainy days

Rainfall and rainy days were calculated as the total rainfall and number of rainy days of different weeks and then finally total all the rainfall and number of rainy days of the tagging weeks.

\section{Results and Discussion}

Weakly meteorological data for seed development period in 2015 is presented in table 2. During 2015 flowering started from $28^{\text {th }}$ June and it continued up to August 29. The fresh opened flowers were tagged daily and their number was recorded on weekly basis for10 weeks. The number of tagged flowers maturing in to well develop opened bolls were the number of retained bolls. These bolls were picked weekly and their number was counted, ginned and same were used for further tests like germination and biochemicals. These results were correlated with different weather parameters. Data on weather parameters i.e. Temperature (Max. and Min.) or $\left(\mathrm{T}_{\max }\right.$ and $\mathrm{T}_{\min }$ ), Relative humidity (morning and evening) or $\left(\mathrm{RH}_{\mathrm{m}}\right.$ and $\mathrm{RH}_{\mathrm{e}}$ ), sunshine hours (SS), rainfall(RF) and rainy days (RD) were recorded for these 10 weeks (Table 2). Range for $\mathrm{T}_{\max }$ during these 10 weeks was $33.0-37.8$, for $\mathrm{T}_{\min }$ it was 23.9 - 26.8, for $\mathrm{RH}_{\mathrm{m}}$ was $72.4-92.7$, for $\mathrm{RH}_{\mathrm{e}}$ was 40.3 - 75.0, for sunshine hours was $2.6-9.5$, for rainfall was $0-77.3$ and for rainy days was $0-4$ during these weeks. Mean $\mathrm{T}_{\max }$ for these 10 weeks was $34.9^{\circ} \mathrm{C} \mathrm{T}_{\min }$ was $25.8{ }^{\circ} \mathrm{C}, \mathrm{RH}_{\mathrm{m}}$ was $85.4 \%, \mathrm{RH}_{\mathrm{e}}$ was $60.7 \%$, sunshine hours were 6.4 hours, rainfall was $220.6 \mathrm{~mm}$ and rainy days were 16 .

Weakly meteorological data for seed development period in 2016 is presented in table 3. During the year 2016 also data were 
recorded in similar way as that of 2015 starting from June 24 to Sept. 1. Temperature (Max. and Min.) or $\left(\mathrm{T}_{\max }\right.$ and $\mathrm{T}_{\min }$ ), Relative humidity (morning and evening) or $\left(\mathrm{RH}_{\mathrm{m}}\right.$ and $\mathrm{RH}_{\mathrm{e}}$ ), sunshine hours (SS), rainfall (RF) and rainy days $(\mathrm{RD})$ were recorded for these 10 weeks (Table 3). Range for $\mathrm{T}_{\max }$ during these 10 weeks was $32.5-38$, for $\mathrm{T}_{\text {min }}$ it was 24.7 - 28.0, for $\mathrm{RH}_{\mathrm{m}}$ was $74.7-94.4$, for $\mathrm{RH}_{\mathrm{e}}$ was $58.3-77.7$, for sunshine hours was $4.2-8.0$, for rainfall was $4-95.5$ and $1-5$ rainy days for these weeks. Mean $\mathrm{T}_{\max }$ for these 10 weeks was $34.9^{\circ} \mathrm{C}, \mathrm{T}$ min was $26.1{ }^{\circ} \mathrm{C}, \mathrm{RH}_{\mathrm{m}}$ was $88.6 \%, \mathrm{RH}_{\mathrm{e}}$ was $69.3 \%$, sunshine hours were 6 hours, rainfall was $338.2 \mathrm{~mm}$ and rainy days were 18 .

Better seed germination (\%) was the direct outcome of better seed development. The seed germination (\%) during in the year 2015 was higher in the period ranging from July, 12 Aug, 15 and in the year 2016 it was from July, 8 - Aug, 11 indicating that period of second week of July to middle of August is most appropriate for seed development under Haryana condition. When we compare the seed germination (\%) during 2015 and 2016, it was lower in the year 2016 and simultaneous comparison of environmental factors during these years indicated the there were large differences in mean values of the year 2015 and 2016 in $\mathrm{RH}_{\mathrm{e}}$ (67.1 and 72.8) and sunshine hours (5.4 and 6.0), where as rest of the environmental factors were almost similar. These results indicated that role of evening humidity is very crucial and persistence of higher $\mathrm{RH}_{e}$ may adversely effect the seed development resulting low seed germination (\%). Longer sun shine hours during 2016 may have adversely affected the seed germination as the distribution of rainfall was erratic and longer sun shine hours may have resulted in moisture deficiency during that period. Similar findings of effect of environmental factors on seed germination (\%) were reported by Ratnam et al., (2014).

Table.1 Sowing dates and different environments in 2015 and 2016

\begin{tabular}{|c|c|c|c|}
\hline \multicolumn{2}{|c|}{ Environment } & \multirow[t]{2}{*}{ Date of Sowing } & \multirow{2}{*}{$\begin{array}{l}\text { Environment } \\
\text { Designation }\end{array}$} \\
\hline Year & Sowing period & & \\
\hline \multirow[t]{3}{*}{2015} & Early & 10 April & $\mathrm{E}_{1}$ \\
\hline & Normal & 15 May & $\mathrm{E}_{2}$ \\
\hline & Late & 5 June & $\mathrm{E}_{3}$ \\
\hline \multirow[t]{3}{*}{2016} & Early & 26 April & $\mathrm{E}_{4}$ \\
\hline & Normal & 5 May & $\mathrm{E}_{5}$ \\
\hline & Late & 2 June & $\mathrm{E}_{6}$ \\
\hline
\end{tabular}


Table.2 Weakly meteorological data for seed development period during 2015

\begin{tabular}{|c|c|c|c|c|c|c|c|c|c|}
\hline \multirow[b]{2}{*}{2015} & \multirow[b]{2}{*}{ Tagging period } & \multirow[b]{2}{*}{ Picking } & \multicolumn{2}{|c|}{$\begin{array}{l}\text { Temperature } \\
\left({ }^{\circ} \mathrm{C}\right)\end{array}$} & \multicolumn{2}{|c|}{$\begin{array}{c}\text { Relative humidity } \\
\%\end{array}$} & \multirow[t]{2}{*}{$\begin{array}{c}\mathrm{SS} \\
(\mathrm{hrs})\end{array}$} & \multirow[t]{2}{*}{$\begin{array}{l}\text { Rainfall } \\
(\mathrm{mm})\end{array}$} & \multirow[t]{2}{*}{$\begin{array}{c}\text { Rainy } \\
\text { days }\end{array}$} \\
\hline & & & $\mathbf{T}_{\max }$ & $\mathbf{T}_{\min }$ & Morning & Evening & & & \\
\hline 1 & 28-June-4 July & 1-Sep & 37.8 & 25.8 & 80.1 & 48.1 & 8.3 & 15.8 & 2.0 \\
\hline 2 & 5-July- 11july & 7-Sep & 34.0 & 26.1 & 86.1 & 70.7 & 2.8 & 46.7 & 1.0 \\
\hline 3 & 12-July- 18 July & 13-Sep & 33.5 & 26.3 & 86.0 & 63.7 & 6.0 & 24.7 & 2.0 \\
\hline 4 & 19-July- 25 July & 20-Sep & 35.6 & 26.7 & 87.3 & 63.0 & 7.3 & 77.3 & 1.0 \\
\hline 5 & 26-July- 1 Aug & 25-Sep & 33.0 & 25.4 & 88.9 & 71.0 & 7.0 & 2.9 & 1.0 \\
\hline 6 & 2-Aug- 8 Aug & 2-Oct & 33.7 & 26.0 & 90.0 & 62.7 & 4.2 & 7.4 & 2.0 \\
\hline 7 & 9-Aug-15 Aug & 9-Oct & 34.3 & 26.8 & 92.7 & 75.0 & 2.6 & 29.2 & 4.0 \\
\hline 8 & 16-Aug-22 Aug & 13-Oct & 34.2 & 26.1 & 88.1 & 57.7 & 6.9 & 7.8 & 2.0 \\
\hline 9 & 23-Aug-29 Aug & 20-Oct & 36.2 & 25.6 & 82.0 & 55.0 & 9.3 & 8.8 & 1.0 \\
\hline 10 & 30-Aug-6Oct & 27-Oct & 37.0 & 23.9 & 72.4 & 40.3 & 9.5 & 0.0 & 0.0 \\
\hline & & & 34.9 & 258 & 85.4 & 60.7 & 64 & 2206 & 160 \\
\hline
\end{tabular}

$\mathrm{T}_{\max }=$ Maximam Temperature $\mathrm{T}_{\min }=$ Minimum Temperature $\mathrm{SS}=$ Sunshine

Table.3 Weakly meteorological data for seed development during period 2016

\begin{tabular}{|c|c|c|c|c|c|c|c|c|c|}
\hline \multirow[b]{2}{*}{2016} & \multirow[b]{2}{*}{ Tagging Period } & \multirow[b]{2}{*}{ Picking } & \multicolumn{2}{|c|}{$\begin{array}{l}\text { Temperature } \\
\left({ }^{\circ} \mathrm{C}\right)\end{array}$} & \multicolumn{2}{|c|}{$\begin{array}{l}\text { Relative humidity } \\
\%\end{array}$} & \multirow[t]{2}{*}{$\begin{array}{c}\text { SS } \\
\text { (hrs) }\end{array}$} & \multirow[t]{2}{*}{$\begin{array}{l}\text { Rainfall } \\
(\mathrm{mm})\end{array}$} & \multirow[t]{2}{*}{$\begin{array}{c}\text { Rainy } \\
\text { days }\end{array}$} \\
\hline & & & $\mathbf{T}_{\max }$ & $\mathbf{T}_{\min }$ & Morning & Evening & & & \\
\hline 1 & $\begin{array}{l}\text { 24-June- } 30 \\
\text { June }\end{array}$ & 28-Aug & 38.0 & 28.0 & 74.7 & 58.3 & 6.7 & 13.0 & 1.0 \\
\hline 2 & 1-July- 7 July & 4-Sep & 35.1 & 26.5 & 90.4 & 71.3 & 5.8 & 93.5 & 3.0 \\
\hline 3 & 8-July- 14 July & 11-Sep & 36.3 & 27.2 & 86.6 & 72.3 & 7.3 & 4.0 & 1.0 \\
\hline 4 & $\begin{array}{l}\text { 15-July- } 21 \\
\text { July }\end{array}$ & 18-Sep & 33.9 & 25.3 & 91.9 & 71.3 & 4.5 & 73.3 & 5.0 \\
\hline 5 & $\begin{array}{l}\text { 22-July- } 28 \\
\text { July }\end{array}$ & 23-Sep & 36.7 & 26.0 & 89.4 & 70.4 & 8.0 & 27.0 & 1.0 \\
\hline 6 & 29-July- 4 Aug & 30-Sep & 32.5 & 25.2 & 93.4 & 74.4 & 4.2 & 47.0 & 1.0 \\
\hline 7 & 5-Aug- 11 Aug & 7-Oct & 34.6 & 26.1 & 91.6 & 75.7 & 6.0 & 4.3 & 1.0 \\
\hline 8 & $\begin{array}{l}\text { 12-Aug- } 18 \\
\text { Aug }\end{array}$ & $11-$ Oct & 34.8 & 24.7 & 85.7 & 60.3 & 6.5 & 4.5 & 1.0 \\
\hline 9 & 19-Aug-25 Aug & 15 -Oct & 34.0 & 26.4 & 88.1 & 61.1 & 5.1 & 8.4 & 2.0 \\
\hline 10 & 26-Aug- 1 Sept & 19-Oct & 32.8 & 25.3 & 94.4 & 77.7 & 6.0 & 63.2 & 2.0 \\
\hline & & & 34.9 & 26.1 & 88.6 & 69.3 & 6.0 & 338.2 & 18.0 \\
\hline
\end{tabular}


Table.4 Seed germination (\%) of different varieties in different environments

\begin{tabular}{|c|c|c|c|c|c|c|c|c|c|c|c|c|c|c|c|c|c|c|}
\hline \multicolumn{10}{|c|}{ H 1098- I } & \multicolumn{10}{|c|}{ H 1300 } \\
\hline Weak & $\mathbf{E}_{\mathbf{1}}$ & $\mathbf{E}_{\mathbf{2}}$ & $\mathbf{E}_{\mathbf{3}}$ & $\mathbf{E}_{\mathbf{4}}$ & $\mathbf{E}_{\mathbf{5}}$ & $\mathbf{E}_{\mathbf{6}}$ & $\mathbf{E}_{\mathbf{1}}$ & $\mathbf{E}_{\mathbf{2}}$ & $\mathbf{E}_{\mathbf{3}}$ & $\mathbf{E}_{\mathbf{4}}$ & $\mathbf{E}_{\mathbf{5}}$ & $\mathbf{E}_{\mathbf{6}}$ & $\mathbf{E}_{\mathbf{1}}$ & $\mathbf{E}_{\mathbf{2}}$ & $\mathbf{E}_{\mathbf{3}}$ & $\mathbf{E}_{\mathbf{4}}$ & $\mathbf{E}_{\mathbf{5}}$ & $\mathbf{E}_{\mathbf{6}}$ \\
\hline $\mathbf{1}$ & 37 & --- & --- & 12 & --- & --- & 28 & & & 11 & & & 21 & & & 8 & & \\
\hline $\mathbf{2}$ & 67 & --- & --- & 16 & --- & -- & 58 & & & 16 & & & 52 & & & 12 & & \\
\hline $\mathbf{3}$ & 72 & 60 & 52 & 42 & 32 & 23 & 61 & 53 & 45 & 32 & 23 & 14 & 56 & 50 & 40 & 31 & 18 & 10 \\
\hline $\mathbf{4}$ & 76 & 65 & 58 & 46 & 36 & 25 & 64 & 56 & 50 & 35 & 24 & 17 & 58 & 54 & 42 & 32 & 19 & 12 \\
\hline $\mathbf{5}$ & 77 & 68 & 62 & 48 & 40 & 27 & 68 & 59 & 52 & 38 & 26 & 20 & 60 & 58 & 46 & 35 & 21 & 16 \\
\hline $\mathbf{6}$ & 79 & 72 & 69 & 51 & 41 & 30 & 72 & 62 & 55 & 43 & 30 & 25 & 62 & 60 & 49 & 36 & 24 & 18 \\
\hline $\mathbf{7}$ & 78 & 75 & 72 & 53 & 43 & 32 & 75 & 63 & 60 & 43 & 33 & 28 & 65 & 63 & 51 & 39 & 27 & 21 \\
\hline $\mathbf{8}$ & 49 & 34 & 28 & 25 & 21 & 16 & 31 & 28 & 22 & 21 & 19 & 18 & 28 & 26 & 20 & 20 & 18 & 12 \\
\hline $\mathbf{9}$ & 25 & 22 & 18 & 19 & 11 & 9 & 20 & 15 & 12 & 16 & 15 & 14 & 18 & 16 & 10 & 15 & 11 & 6 \\
\hline $\mathbf{1 0}$ & 15 & 12 & 9 & 12 & 10 & 5 & 9 & 8 & 6 & 10 & 6 & 3 & 9 & 8 & 5 & 9 & 4 & 3 \\
\hline Mean & 57 & 51 & 46 & 32 & 29 & 21 & 49 & 43 & 38 & 26 & 22 & 17 & 43 & 42 & 33 & 24 & 18 & 12 \\
\hline
\end{tabular}

Table.5 Environmental factors for proper seed germination and their optimum range in 2015 and 2016

\begin{tabular}{|c|c|c|c|}
\hline Environmental factors & 2015 (12 July- 15 Aug) & 2016 (8 July- 11 Aug) & $\begin{array}{c}2015 \& \\
2016\end{array}$ \\
\cline { 2 - 4 } & Mean & Mean & Mean \\
\hline $\mathrm{T}_{\max }$ & 34.0 & 34.8 & 34.4 \\
\hline $\mathrm{T}_{\min }$ & 26.2 & 26.0 & 26.1 \\
\hline $\mathrm{RH}_{\mathrm{m}}$ & 89.0 & 90.6 & 89.8 \\
\hline $\mathrm{RH}_{\mathrm{e}}$ & 67.1 & 72.8 & 70.0 \\
\hline $\mathrm{SS}$ & 5.4 & 6.0 & 5.7 \\
\hline $\mathrm{RF}$ & 28.3 & 31.12 & 29.71 \\
\hline $\mathrm{RD}$ & 2 & 1.8 & 1.9 \\
\hline
\end{tabular}

$\mathrm{T}_{\max }=$ Maximam Temperature $\quad \mathrm{T}_{\min }=$ Minimum Temperature $\quad \mathrm{RH}_{\mathrm{m}}=$ Morning Relative Humidity $\mathrm{RH}_{\mathrm{e}}=$ Evening Relative Humidity SS= Sunshine

$\mathrm{RF}=$ Rainfall $\quad \mathrm{RD}=$ Rainy Days

Seed germination $(\%)$ of different varieties in different environments is given in table 4 . In the variety $\mathrm{H}$ 1098- I, average seed germination of 10 weeks had wide differences in different environments i.e.57, 51, 46, 32, 29 and 21 in $\mathrm{E}_{1}, \mathrm{E}_{2}, \mathrm{E}_{3}, \mathrm{E}_{4}, \mathrm{E}_{5}$ and $\mathrm{E}_{6}$ respectively. Range of seed germination in $\mathrm{H}$
1098- I was 5\% - $79 \%$ across all the six environments. It was observed that seed germination was high in $E_{1}$ and $E_{4}$ when we compare the environments of both the years. In the variety $\mathrm{H} 1300$ average seed germination of 10 weeks was $49,43,38,26$, 22 and 17 respectively. Range of seed 
germination in $\mathrm{H} 1300$ was $3 \%-75 \%$ across all the six environments Seed germination was high in $E_{1}$ and $E_{4}$ when we compare all the environments of 2015 and 2016. In the variety $H 1316$ average seed germination was 43, 42, 33, 24, 18 and 12 respectively. It was high in E1 and E4. Range of seed germination in the variety $\mathrm{H} 1316$ was $3 \%-65 \%$ across all the six environments. So seed germination was higher environments in $E_{1}$ and $E_{4}$ i.e. in early sown conditions of both the years. These finding indicated that environmental factors were favorable for seed development in early sown conditions during both the years. These results confirm the earlier findings of Bange and Milroy, 2004.

Seed germination was higher in the seed development period from July, 12- Aug, 15 in 2015 and July, 8 - Aug, 11 in the year 2016 (Table 5). There were differences in some environmental factors such as $\mathrm{RH}_{\mathrm{e}}$, sunshine hours and rainfall in year 2015 and 2016 leading to differences of mean of these environmental factors. During 2015 mean value of $\mathrm{T}_{\max }$ was $34^{\circ} \mathrm{C}, \mathrm{T}_{\min }$ was $26.2, \mathrm{RH}_{\mathrm{m}}$ was $89 \%$, $\mathrm{RH}_{\mathrm{e}}$ was 67.1, sunshine hours were 5.4, rainfall was 28.3 and rainy days were 2. During 2016 mean value of $\mathrm{T}_{\max }$ was $34.8^{\circ} \mathrm{C}$, $\mathrm{T}_{\text {min }}$ was 26.0 , $\mathrm{RH}_{\mathrm{m}}$ was $90.6 \%, \mathrm{RH}_{\mathrm{e}}$ was 72.8 , sunshine hours were 6 , rainfall was 31.12 and rainy days were 1.8. Pooled mean of environmental factors during 2015 and 2016 for $\mathrm{T}_{\max }$ was $34.4^{\circ} \mathrm{C}$, $\mathrm{T}_{\min }$ was $26.1^{\circ} \mathrm{C}, \mathrm{RH}_{\mathrm{m}}$ was $89.8 \%, \mathrm{RH}_{\mathrm{e}}$ was $70 \%$, for SS was 5.7 hours, rainy days was 29.71 and rainy days were 1.9 . Benefits of temperature were also documented by Sankaranarayanan et al., (2010) and Reddy et al., (1991). These results indicates that although the environmental factors are beyond our control but by adjusting sowing period it is possible to obtain higher yield with better seed quality.

\section{References}

Bange, M.P. and Milroy, S.P. (2004). Growth and dry matter partitioning of diverse cotton genotypes. Field Crops Res. 87(1): 73-87.

Blanc, E., Quirion, P., and Strobl, E. (2008). The climatic determinants of cotton yields: Evidence from a plot in West Africa. Agric. Forest Meteorology.

ICAR-All India Coordinated Research Project on Cotton Annual Report 2016-2017.

Malagouda, P. Khadi, B.M. Basamma, K. and I.S. Katageri (2014).Genetic Variability and Correlation Analysis for Fibre Quality Traits in Diploid Cotton (Gossypium spp). J. Agric. \& Environ. Sci. 14 (5): 392-395.

Ratnam, M., Reddy, S.K., Bharathi, S. (2014). Influence of weather parameters on growth and yield of Bt cotton under krishina agro climatic zone of Andhra Pradesh. J. Cotton Res. Dev. 28(2): 214-216.

Reddy, V.R., Baker, D.N. and Hodges, H.F. (1991). Temperature effects on cotton canopy growth, photosynthesis, and respiration. Agron. J. 83: 699-704.

Sankaranarayanan, K., Praharaj, C.S., Nalayani, P., Bandyopadhyay, K.K., Gopalakrishanan, N. (2010). Climate change and its effect on cotton (Gosssypium sp.). Indian J. Agric. Sci. 80:561-575.

\section{How to cite this article:}

Pinki, S.S. Siwach and Neha Rohila. 2018. Meteorological Parameters: Effect of Different Environments on Seed Germination in Upland Cotton (Gossypium hirsutum L.). Int.J.Curr.Microbiol.App.Sci. 7(12): 1192-1197. doi: https://doi.org/10.20546/ijcmas.2018.712.148 